\title{
Nursing leadership in the European landscape: influence, reality and politics
}

\section{Mary Gobbi}

University of Southampton, Southampton, UK

\begin{abstract}
Demonstrating the impact and effectiveness of nursing leadership, influence and power within the European space is a challenging endeavour. Using the example of the European Directive on Professional Qualifications (2005/36/EC) and its successor legislation (Modernised Directive $2013 / 55 / E U)$, this paper reviews the collaborative strategies, drivers and leadership actions which have influenced the recent legislation, albeit without complete success. Looking to the future, it is argued that nursing will struggle to achieve further positive political outcomes until there is a more coherent, assertive and collaborative leadership at pan-European level. Given the complexity of the European 'trilogue', namely the co-decision powers and interactions between the European Parliament, Commission, and Council, it is essential that far-reaching and sustained network(s) of influence are established within each country, including prospective accession countries. A failure to co-ordinate, co-operate, strategically lobby, garner research evidence and argue for standards of education, practice, care and workforce conditions, could lead to significant threats to public protection and safety. Drawing upon the related historical and contemporary context, sources of contemporary leadership, 'absent and strident voices' and European Union (EU) policy drivers, recommendations for future leadership directions are proposed. Political engagement is crucial to enabling reforms for the next Directive revision.
\end{abstract}

\section{Keywords}

regulation, nursing, leadership, Europe, political policy

\section{Introduction}

This paper draws on over a decade's personal experience, observations and encounters with European policies and projects related to nurse education, research and health care workforce trends. Officially the journey commenced with my engagement in the European 
Union (EU) Socrates 'Tuning Project' in 2003, which led to the development of validated pan-European competences for bachelor's-level nursing. The competences were designed to meet and exceed the requirements of the then European legislation concerning the "nurse responsible for general care' (Gobbi et al., 2009). Such legislation was quickly identified as being in need of modernisation to reflect contemporary health needs and the role of the graduate registered nurse. Furthermore, in the interests of public safety, the Directive needed to accommodate language proficiency, levels of capability and negative personal characteristics such as records of abuse. This attempt to change European legislation was ambitious, particularly in the period 2003/2004 when politically the EU was enabling 10 countries to accede in 2004.

As a nurse responsible for general care, my own nurse training in the United Kingdom (UK) was itself determined by the then Sectoral Directives 77/452/EEC and 77/453/EEC. A 'directive' is a law that sets aims and makes requirements that all EU countries must achieve. These Directives specified the minimum training requirements for 'Nurses Responsible for General Care' who held mutual recognition. This meant that the holder of the qualification was legally entitled to be recognised automatically in other European Economic Community (EEC) Countries. Both Directives had been developed in the 1960s and early 1970s when the then EEC comprised only nine countries who achieved a consensus, unanimous decision and vote. At that time, very few nursing courses were in higher education, fewer at graduate/bachelor's level, and certainly no countries had mandatory graduate status with registration at national level.

The minimum training requirements specified 10 years of general education before training; duration of training (3 years, 4600 hours); minimum proportions of clinical $(50 \%)$ and theoretical training (one-third); content of the curriculum in theory and practice; and conditions related to the teaching and supervision of students. Other professional sectors at that time, including medicine, pharmacy and veterinary surgeons, were already at bachelor's level. These professions often had specialist post-licence/ registration qualifications which were also embedded in the legislation. Midwifery, like nursing (another female-dominated occupation in Europe), was not in higher education and rested in the vocational sector.

Subsequent iterations of the Directives occurred in Directive 89/595/EEC which was summarised in conselg 1977L0453 dated 31/7/2001 (see Keighley, 2009). Despite attempts to achieve the same status for other specialties in nursing (e.g. the then psychiatric and paediatric nursing registrations), the professions that were not 'harmonised' were covered by the General Systems Directive (89/48/EEC of 21 Dec. 1988). All these directives were superseded by Directive 2005/36/EC on the Recognition of Professional Qualifications which came into force on 20 October 2007. However, the minimum training requirements had not changed between the 1977 Directives and the 2005 Directive, despite the passage of nearly 30 years in a nursing world characterised by a rapidly expanding knowledge base, increasing professionalisation, fast-emerging technologies, new modes of education and training, new health and demographic challenges, and increasing movement of peoples and staff.

Earlier attempts to modernise the Directive had failed, including one to introduce competence-based education in the 1990s. The failures were due in part to the EU requirement for consensus, but also aggravated by an expanding membership of the EU, an increasing divergence of nursing roles and, perhaps more importantly, no political will to effect change. It is noteworthy that some countries such as the Republic of Ireland, the Netherlands and the UK used the terms of their Presidency to promote change. 
Indeed personal enquiries, on behalf of the Tuning group, made to the EC (European Commission) to ascertain the process for revision were met with rebuttal in 2003/2004. However, before taking this story forward, three other background and contextual factors need consideration: first, the situation of nursing in Europe between 1977 and 2007; second, the mechanisms for effecting change to the Directive; and third, the exploitation of windows of opportunity through leadership, coalitions, use of research evidence and knowledge sharing.

\section{European nursing 1977-2009}

For the nine countries that contributed to the 1977 Directive, nursing was primarily still hospital based with associated schools of nursing. The similarities at that time outweighed the differences and there was no significant movement of staff between the countries. A standing committee emerged from the Permanent Committee of Nurses (PCN) in Liaison with the EEC and linked formally to the EC with rights to seek information from the Commission and in turn offer advice. Dame Sheila Quinn - a key nursing leader - was elected as the first President of the EEC Advisory Committee on Training in Nursing (ACTN) (see the University of Sheffield Archives, no date). This Committee did have powers to propose Directives; it attempted to reform the Annex to the General Nursing Directive to no avail. Eventually these committees were disbanded, although in the process the European Federation of Nurses (EFN) emerged.

Incremental expansion of the EU occurred, with the first 'Soviet legacy model' of nurse education entering the EU when West Germany merged with East Germany following the collapse of the Berlin Wall in 1989. For the first time, a significantly different model of nursing was introduced to the EU. Nurses were viewed as being below the 'Feldsher', often having lower status and value. The Feldsher first emerged in Medieval Germany to assist with those injured in combat (Murray, 2004). The concept was adopted successfully by Russia in the nineteenth century, although traditional 'Nightingale' and religious orders also existed. Following the Russian Revolution, reforms of the state system led to the 'comrade nurse' and 'Feldsher', both directly accountable to the physicians who trained them. Feldshers held a more technical role akin to a medical assistant, with a degree of autonomy not held by nurses (see Quinn, 1968; Salvage and Heijnen, 1997; Uhlich et al., 2007). Hence, for many accession countries with a Soviet legacy of medical, feldsher and nurse training, if their nurse education had not already begun to reform, they needed significant modification and in some cases restructuring in order to meet the EU criteria. In the period 2004-2007, 12 countries joined the EU. Some struggled to meet these criteria for the general nurse.

The benefits of the minimum training requirements were clearly a vehicle to improve nurse education for some countries, while for others, the training requirements were not only too low, they lacked depth and breadth of content. Indeed, the goals of the World Health Organisation's Munich Declaration of 2000 (WHO, 2000) were aspirational for many with respect to nurse involvement in all levels of decision making, medical dominance, access to higher education and continuing professional development, interprofessional learning, developing research and evidence-based practice, and family-focused community nursing with public health and health promotion roles. Historically, particularly during the apprenticeship model, nursing education tended to be managed from national Ministries of Health or Social Welfare rather than Education Ministries. When nurse education moves 
into higher education, then Education Ministries become involved, sometimes taking complete control and sometimes working through agreements with Ministries of Health. According to the country tradition, the financial systems are different; some nursing students are waged, some treated as other university students and others will have a special educational grant or bursary.

During the 1980s and 1990s, more countries either moved into, or associated their nurse education system with, higher education and thus promoted the move to academic accreditation and bachelor-level education. This move to a graduate bachelor's profession has been argued in the interests of patient safety and public health by the International Council of Nurses (ICN, 2003, 2004), World Health Organisation and Sigma Theta Tau International (2007), and the Global Alliance for Leadership in Nursing Education and Science (GANES, http://ganes.info/home.php) to name a few.

The pace at which the general and higher education systems reformed varied and, when combined with the realisation of the single market 'four freedoms' of movement of goods, services, people and money, the heterogeneity of nursing within the European space was becoming increasingly apparent. This was most evident following the 12 country admissions during 2004-2007. Key country differences included:

- education and training: academic entry and exit levels, curriculum design and content, particularly whether input or output; available educational resources and the range, type and amount of clinical experiences available to students;

- the nursing scope of practice (the roles and tasks that they are authorised to perform like giving or prescribing medicines or therapy);

- the social and economic status held in society - particularly in relation to doctors;

- the extent to which nurses undertake roles due to the skill mix with other professions, and other non-professional grades;

- the form of regulation/competent authority (e.g. governmental department versus independent regulator or professional association);

- whether the legal title is protected in law (see International Council of Nurses, 2004);

- the extent of ethical and professional codes of practice;

- quality assurance mechanisms for curricula and clinical practice.

In some countries, recruitment problems and an ageing workforce were also influencing policy. By 2006, five member states reported that nearly half their nurses were over 45 (WHO, 2006) and internal EU migration was fast becoming a reality, with the differences in nurse training and education causing practical challenges on the ground. Meanwhile, a growing awareness of the economic and political challenges facing the EU with respect to health needs, and the concomitant demand for a suitably qualified health care workforce, was gathering momentum. It was evident that there was a dearth of reliable data and research concerning health care professional mobility, workforce and connections with patient outcomes (European Commission, 2008). Higher education reforms were running concurrently under the action lines launched through the Bologna Process (Bologna Declaration, 2009). The key components were stakeholder engagement; the move to competence/learning outcome-based education; a student-centred approach; the introduction of a European Credit and Transfer System (ECTS); quality enhancement mechanisms; and a focus on learning, teaching and assessment aligned to programme outcomes. That change was happening was confirmed in the WHO report for Europe (Buscar et al., 2009). 
It was in this heady mix that the Tuning team, along with other significant partners, sought to amend the Directive to better reflect modern, contemporary nursing at graduate level. To achieve this goal, it was necessary to appreciate the workings of pan-European nursing organisations and the political processes involved in changing an EU Directive.

\section{Directives, gathering momentum and allies}

While the preliminary enquiries to establish the mechanism to proceed with changes to the then Directive were met with a curt reply in 2003/2004 - perhaps understandably so given the influx of new countries - the 2005/36/EC Directive had been implemented with a provision for a mandatory 5-year evaluation. This provided a window of opportunity which was later exploited. It was evident that there were significant anomalies between the Bologna Process, the Directive requirements and the education training needs of bachelor's level student nurses (Gobbi, 2011). The Directive itself is under the remit of The Internal Market and Services Directorate General (DG MARKT), one of the Directorates General which make up the EC. The Bologna Process was within the jurisdiction of DG Education and Culture (EAC) while health and workforce matters are covered by DG Health and Consumers (SANCO) and DG Employment and Skills (DG EMPL). DG MARKT is the most powerful Directorate as it deals directly with the Lisbon Treaty and the laws, steering legislation through the 'trilogue' process and then monitoring and enforcing compliance. Health and educational matters are a national, not European, jurisdiction and thus operate at a 'voluntary agreement' level. While a legal change involves DG MKT, the other Directorates would also have a stake in the process and outcomes. DG EAC and the Tuning Leaders arranged a meeting with DG MKT in 2007 (see below).

In 2003, there were very few pan-European platforms representing the key stakeholding groups. One influential and active group, the EFN was a prominent voice and developed several position statements on the Directive, the Bologna Process and Continuous Professional Development. Pan-European activity emerged again; for example in April 2004, the Chief Nursing Officers convened under the Irish Presidency and there was a launch of a network of European Nurse Regulators (FEPI). The Tuning group worked on developing the competences, conducting a survey, networking and gathering a representative European panel, chaired by an independent non-Nurse academic, with an external panel member from the USA. This process of engagement, including students and service users, gathered momentum concerning the common goal of graduate nurse education, enabled a consolidated position to emerge with arguments rehearsed, rebutted and compromises achieved. By 2006 collaborative support had been given by the EFN, the European Council of Nursing Regulators (FEPI), the European Federation of Nurse Educators (FINE), the European Nurse Directors Association (ENDA) and the International Council of Nurses. The role and commitment of the executive leaders in these associations and the work undertaken by their officers cannot be underestimated. Without their 'front and back stage' support, the momentum would not have been sustained. The common goal was the development of a competent graduate who is an independent and autonomous practitioner well equipped to meet the current and future health care needs of society. The Tuning Survey was updated in 2008 and reached additional countries, including France, Italy, Lithuania and Portugal. 


\section{Windows of opportunity, technical expertise and a global recession}

The day before the validation event in 2007, a crucial preparatory meeting occurred with a representative of DG MKT. Concerns had been expressed that the Tuning initiative was somehow undermining due process and the influence of the Bologna Process was in conflict with the Directive. During this challenging meeting, it became apparent that DG MKT had not appreciated the rapid changes that were unfolding in nursing and education in many countries, in particular the extending scope of practice, degree of autonomy, changing health needs, educational developments and academic levels of registered nurses. In the context of the driving forces of the 'four freedoms' expressed in principles and legislation, it was made clear that while countries could exceed the minimum training requirements for quality reasons, they could not reject legitimate applicants from other EU countries whose training fulfilled the Directive specifications.

In other words, nurses with little experience of autonomy or evidence-based practice could practice in countries with significant autonomy and research - and vice versa. Despite a lengthy dialogue, no resolution appeared forthcoming, although the procedure 'Comitology' to modify the Directive was mentioned. This procedure had never been invoked and thus there was no precedent for its implementation. Consistent attempts to educate civil servants became a necessary endeavour by all the nursing stakeholders. In a follow-up correspondence received from DK MKT (July 2007) it was stated that:

the basis of the recognition systems for sectoral professions should be taken into account during the whole tuning exercise, namely that the development of learning outcomes can in no way come instead of, in addition or at subsidiary order to the professional qualification.

In the midst of these debates, DG MKT subsequently invoked procedures against the Flemish part of Belgium for breaching the Directive. At the heart of this conflict was the introduction of the Bologna Process and accreditation of prior learning within the national law (see Boomgaert and De Decker, 2010). The stakes were high. This episode reinforced the relative impasse of the 2007 meeting, demonstrating that there had to be a resolution of the interface between the spirit of the educational reforms within the Bologna Process, the rigid strictures of the input-oriented Directive and the current requirements of nurse education.

Similar dialogues were taking place with other stakeholders, who also reinforced the core messages, including WHO (Hallet and Wagner 2011). The steps to evaluate the Directive were finally established and a series of open and closed dialogue meetings occurred, Green Papers were issued and consultations commenced. Formal rather than informal collaborations were necessary to work with other health professional groups sharing similar concerns about the workings of the Directive (e.g. Medicine). The UK collaborative networks shared intelligence and identified common ground and points of difference between the various health care sectoral professions. Throughout national and European facilitated meetings, round tables, public debates in the European Parliament, national forum events or nursing conferences, nurse leaders were supporting, guiding, collaborating, engaging sympathetic politicians and liaising one with another. Due credit must be given to the executives and officers of EFN, ENDA, FEPI, FINE and other nursing organisations, for their sterling work. Similarly during the dialogue process, there were plenty of opportunities to interact with the DGs EAC, MKT and SANCO.

Meanwhile, a series of EC-commissioned research and policy studies had been launched to investigate the health care workforce, mobility (Wismar et al., 2012), nurse burnout, staffing and patient outcomes, (Aiken et al., 2012) and nursing skills (Gobbi et al., 2013). DG EMPL 
was sponsoring the EU Skills Panorama initiative which included the health care workforce. Nursing was now on the political agenda for a variety of reasons, regretfully sometimes due to high-profile cases where training and language differences led to malpractice. As the various projects produced their preliminary and final findings, the evidence base and technical expertise within the profession was growing. Using Kingdon's (2010) analysis of public policy impact, three of the four elements were coming together, namely:

(a) the problem was clear and there was significant consensus - need to upgrade the minimum training requirements;

(b) the policy landscape was present and converging - e.g. from research, economics, workforce and health needs;

(c) the policy window was present - the timeliness of the evaluation of the directive.

However, the fourth element, the political dimension was still in its infancy.

\section{Achievements and disappointments}

By 2012, when the evaluations and consultation exercises concerning the Green Paper culminated in the proposals for the Modernised Directive, the influence from data and arguments was evident. It was noted that of the then 27 member states, 16 countries delivered their nurse education in higher education only and 25 member states used competences at the national level.

The potential for reform looked positive, but the political will was not present in all countries. Sometimes the nursing voice was weak, but this was not always the case. Some politicians and leaders were worried that raising the entrance level to 12 years would cause recruitment problems and undervalue their current nursing workforce, and when combined with the financial recession or local party/country politics, a few countries objected to the 12-year admissions criteria. The parliamentary debate proceeded, with some wins and some losses. The Modernised Directive will be transposed by 2017 and it will be evaluated - there is another chance for change! In the battle to obtain graduate status for nursing, European Nurse leaders have moved the goal posts and demonstrated technical expertise, resilience and the ability to collaborate. However, they/we have also encountered the might of political party politics at both European and national levels, and the absence of nursing power and voices in some countries. To achieve further successes and effective engagement, nurse leaders must ensure there is active national and pan-European engagement at four levels:

(1) collaboration with stakeholding groups - an active presence of regulators, educators (vocational and higher education), managers, (Chief Nurses, Directors of Nursing/ employers), researchers, professional associations/trade unions, student and patient associations;

(2) effective sustained lobbying over a period of years to educate civil servants and persuade members of the National and European Parliaments - necessary to garner political momentum and carry the next vote;

(3) work towards achieving the Munich Declaration goals within each country;

(4) use the opportunities presented by the EU Presidencies to keep the momentum going; this needs assistance from the Chief Nurses, competent authorities and nurses with political national power. 
Table I. Summary of the leadership process adapting Kotter's 8-step model - an iterative process.

\begin{tabular}{|c|c|c|}
\hline Kotter's steps & Nursing action/motivating factor & Political drivers/actions \\
\hline $\begin{array}{l}\text { Creating a sense of } \\
\text { urgency }\end{array}$ & $\begin{array}{l}\text { - Tuning timetable } \\
\text { - Concerns for patient safety due } \\
\text { to inadequacies of current } \\
\text { Directive } \\
\text { - Emergence of networks }\end{array}$ & $\begin{array}{l}\text { - Evaluation planned 2005/36/EC } \\
\text { COM (20II) Green Paper. } \\
\text { Modernising the Professional } \\
\text { Qualifications Directive } \\
\text { - Crucial cases where poor training } \\
\text { standards had led to high-profile } \\
\text { deaths }\end{array}$ \\
\hline $\begin{array}{l}\text { Creating the } \\
\text { coalition }\end{array}$ & $\begin{array}{l}\text { - Relationships created during } \\
\text { Tuning validation process } \\
\text { - Existing pan-European } \\
\text { organisations } \\
\text { - Relationships made, new } \\
\text { audiences reached through the } \\
\text { partner networks } \\
\text { - Conference attendances }\end{array}$ & $\begin{array}{l}\text { - Networks created through the } \\
\text { revision and evaluation process } \\
\text { (Nursing and Midwifery Council } \\
\text { UK facilitator) } \\
\text { - Meetings convened for } \\
\text { consultation, advice and research } \\
\text { dissemination provided platforms } \\
\text { for specialist debate }\end{array}$ \\
\hline $\begin{array}{l}\text { Developing the } \\
\text { vision }\end{array}$ & $\begin{array}{l}\text { Significant consensus on } \\
\text { - graduate nurse education } \\
\text { - competence framework } \\
\text { - raised admission criteria to } 12 \\
\text { years } \\
\text { - language criteria } \\
\text { - patient safety through regulated } \\
\text { disclosure of criminal behaviours }\end{array}$ & $\begin{array}{l}\text { - Political goals, free movement, } \\
\text { professional card } \\
\text { - Green Paper on the Health Care } \\
\text { Workforce COM } 2008 \\
\text { - Results or early findings of } \\
\text { research studies and EU } \\
\text { Observatories }\end{array}$ \\
\hline $\begin{array}{l}\text { Communicating the } \\
\text { vision }\end{array}$ & $\begin{array}{l}\text { - Clear articulated vision, } \\
\text { conference presentations, } \\
\text { meetings, and training sessions } \\
\text { - Champions in key organisations }\end{array}$ & \\
\hline $\begin{array}{l}\text { Empowering broad } \\
\text { based action }\end{array}$ & $\begin{array}{l}\text { Collaboration with other disciplines } \\
\text { and organisations }\end{array}$ & $\begin{array}{l}\text { EU Action Plans from DG SANCO } \\
\text { and EMPL } \\
\text { EAC Bologna Process and links with } \\
\text { Bologna follow-up group and } \\
\text { European Universities } \\
\text { Association }\end{array}$ \\
\hline $\begin{array}{l}\text { Generating a 'quick' } \\
\text { win }\end{array}$ & \multicolumn{2}{|c|}{$\begin{array}{l}\text { Some changes evident in the Modernised Directive } \\
\text { Not all achieved especially } 12 \text {-year entry }\end{array}$} \\
\hline Never letting up & $\begin{array}{l}\text { Follow-up meeting convened under } \\
\text { the Irish Presidency with an } \\
\text { action plan }\end{array}$ & $\begin{array}{l}\text { Following transposition in } 2017 \\
\text { Directive will need evaluation }\end{array}$ \\
\hline $\begin{array}{l}\text { Incorporating } \\
\text { change within } \\
\text { the European } \\
\text { culture }\end{array}$ & $\begin{array}{l}\text { Reinforcement of core messages; } \\
\text { leadership }\end{array}$ & $\begin{array}{l}\text { An acknowledgement that change is } \\
\text { needed, if only for economic } \\
\text { reasons. } \\
\text { Policy initiatives }\end{array}$ \\
\hline
\end{tabular}




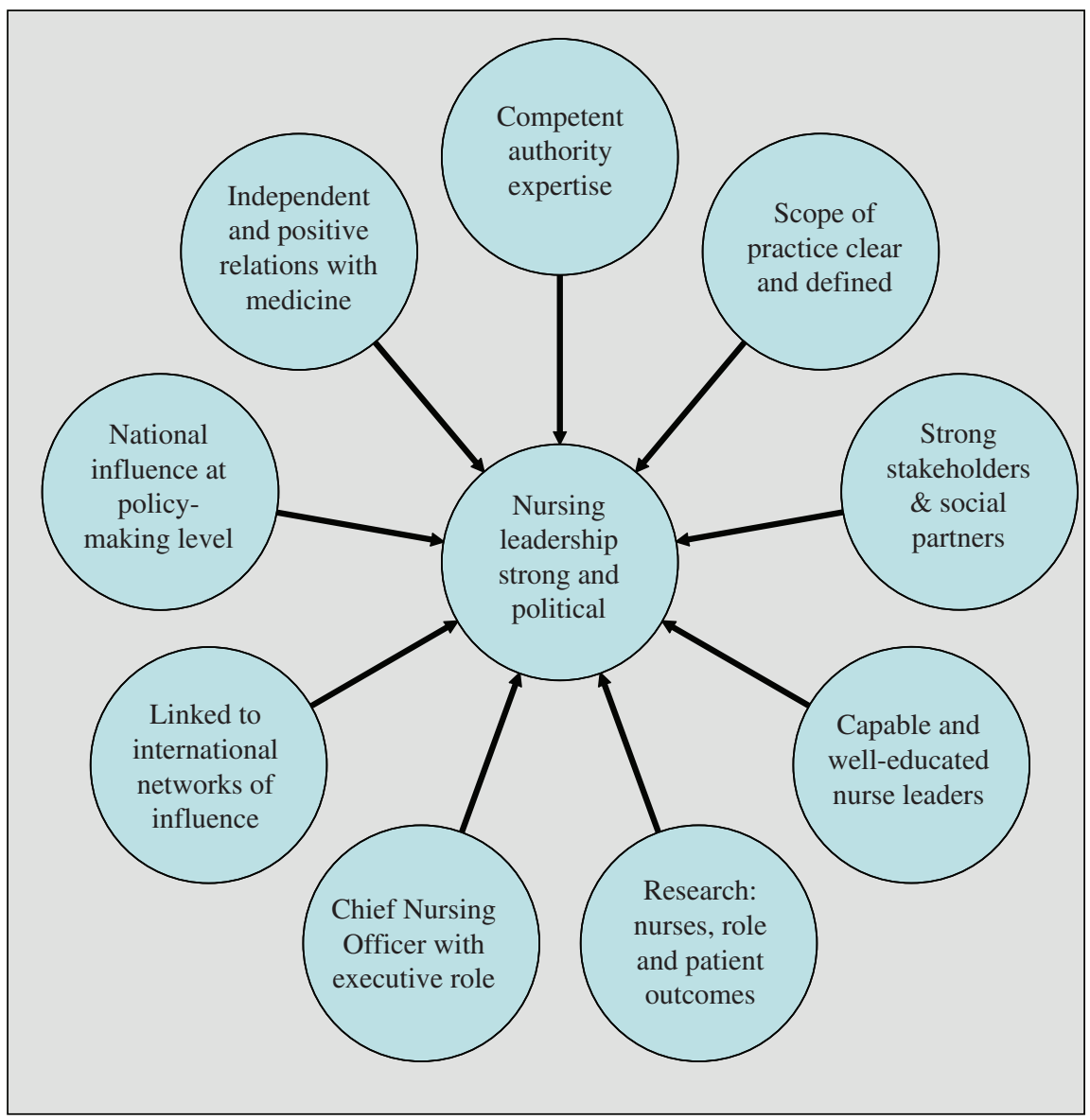

Figure I. Factors influencing nursing and its leadership capacity at the EU Level.

Table 1 uses Kotter's change model (Kotter, 2007) to show the links to successful change, while Figure 1 summarises the factors that are necessary for effective, strong and competent politically engaged nurse leadership.

However, at the pan-European level, there is a noticeably absent European Council of Deans of Nurse Education: a group that would complement EFN and FINE and enable further movement through the vocational and higher education systems. Similarly, the membership of FEPI is small, and while the informal networks gathered together for the Directive review were active, this network needs to be sustained. The excellent work undertaken by nurse researchers in the field of factors influencing patient outcomes also needs to be continued.

\section{Conclusions and next steps}

With a new European Parliament, it is not yet clear what the drivers will be, nor who will be the key figures in the committees. There will be new windows of opportunity, some threats due to 
recession and economic constraints, and a huge nursing workforce which is seen as a political economic vehicle for recovery. Examples of threats/opportunities include the possibility to extend automatic recognition for nurse specialisms through the use of common training principles. Work will be needed on the development of the nursing competences and the future introduction of ECTS. However, it is crucial to be alert to the underpinning drivers at EU level; as Commissioner Barnier stated (12/06/2013) when the Directive was passed:

The modernisation of this directive is an important measure in our strategy to relaunch the European economy. In creating a more efficient system for recognition of professional qualifications, it will contribute to dealing with the labour shortage in Europe and will come to the aid of highly qualified job seekers, in particular the young.

As Churchill stated:

Now this is not the end. It is not even the beginning of the end. But it is, perhaps, the end of the beginning (Winston Churchill, 1942).

So in the context of graduate nurse education and modernising the Directive, nurse leaders are required for the long haul, a 10-year trajectory for two revisions of the Directive, the management of any new accession countries, and the goal of improving patient safety and care through minimum training standards that are contemporary, fit for purpose and high enough to meet the health and well-being needs of each individual European citizen.

\section{Key points for policy, practice and/or research}

- Nursing leadership in Europe requires continuity and long-term vision.

- There is an absent voice of nurse-led regulation and free-speaking Chief Nurses in many countries.

- There is an absent voice at EU level from the European Universities that contain nursing departments.

- It is crucial for nurse leaders to utilise the rotational EU Presidency so as to facilitate change and keep momentum.

- Country-based nurse leaders, whether in official or unofficial roles, must work to influence Members of the National and European Parliaments, especially those on key committees.

- The 'C's: collaboration, co-ordination, coalition, communication, consistency.

- There are continual threats to the integrity of nurse training and education - political and policy vigilance is necessary.

\section{Acknowledgements}

The numerous colleagues from the pan-European organisations who have granted me the privilege of working with them in our ongoing journey to improve standards of patient care through standards of education. The architects of the Tuning Project for launching graduate nurse education onto the EC European Agenda.

\section{Declaration of conflicting interest}

None declared. 


\section{Funding}

This research received no specific grant from any funding agency in the public, commercial, or not-forprofit sectors.

\section{References}

Aiken L, Sermeus HW and Van den Heede K (2012) Patient safety, satisfaction, and quality of hospital care: Cross sectional surveys of nurses and patients in 12 countries in Europe and the United States. British Medical Journal 344(7851): 1717.

Bologna Declaration (1999) Bologna Declaration of $19^{\text {th }}$ June 1999. Joint Declaration of the European Ministers of Education. Available at: http://ec.europa.eu/education/ policy/higher-education/bologna-process_en.htm.

Boomgaert W and De Decker F (2010) Tensions between the Bologna process and Directive 2005/36/EC in respect of nursing education: The Flemish case. Journal of the European Higher Education Area C 5: 1-9.

Buscar A, Sivertsen B and White J (2009) Nurses and Midwives: A force for health. Survey on the situation of nursing and midwifery in the Member States of the European Region of the World Health Organization. Copenhagen: WHO. Available at: www.euro.who.int/_data/assets/pdf_file/0019/114157/ E93980.pdf.

European Commission, COM (2008) Green Paper on the European Workforce for Health. Brussels: EC

Gobbi M (ed.) (2011) Reference Points for the Design and Delivery of Degree Programmes in Nursing. Tuning Educational Structures in Europe. Spain: University of Deusto.

Gobbi M, Bremner J and Giepmans P (2013) Feasibility Study on the Establishment of a European Sector Council on Employment and Skills for Nursing and the Care Workforce. Final Report to DG EMPL.

Hallet C and Wagner L (2011) Promoting the health of Europeans in a rapidly changing world: A historical study of the implementation of World Health Organisation policies by the Nursing and Midwifery Unit, European Regional Office, 1970-2003. Nursing Inquiry 18: 359-368.

International Council of Nurses (ICN) (2003) ICN Framework of Competences for the Generalist Nurse. Geneva: ICN.

International Council of Nurses (ICN) (2004) Scope of Nursing Practice. Geneva: ICN. (Revision of 1998 version.).
Keighley T (2009) European Union Standards for Nursing and Midwifery: Information for Accession Countries, 2nd ed. Copenhagen: WHO Regional Office.

Murray E (2004) Russian nurses from the Tsarist Sister of Mercy to the Soviet comrade nurse: A case study of absence of migration of nursing knowledge and skills. Nursing Inquiry 11: 130-137.

Kingdon J (2010) Agendas, Alternatives, and Public Policies. Updated $2^{\text {nd }}$ ed., with an Epilogue on Health Care (Longman Classics in Political Science). Edinburgh: Pearson.

Kotter JP (2007) Leading change: Why transformation efforts fail. Harvard Business Review. January: 96-99.

Official Journal of the European Communities (1977) Legislation. Vol. 20. No. 176. $15^{\text {th }}$ July 1977.

Quinn SM (1968) Nursing in the Soviet Union. International Nursing Review 15(1): 75-86.

Salvage J and Heijnen S (1997) Nursing in Europe: A Resource for Better Health. WHO regional publications. European series; No. 74. ISBN 9289013389.

Uhlich C, Michaud SL and Giblin C (2007) Canadians Partner with Russians to Advance Nursing Reforms. Canadian Nurse 103(6): 10-12.

University of Sheffield Archives (no date) Available at: http:/ www.sheffield.ac.uk/library/special/euronurs (accessed 20th August 2014).

Wismar M, Maier CB, Glinos IA, et al. (2012) Health Professional Mobility and Health Systems. Observatory Series no 23. Copenhagen: WHO/European Observatory on Health Systems and Policies.

World Health Organisation (WHO) (2000) Munich Declaration: Nurses and Midwives: A Force for Health, 2000. Copenhagen: WHO Regional Office for Europe.

World Health Organisation (WHO) (2006) Observatory Policy Series. WHO/European Observatory on Health Systems and Policies. Copenhagen, Denmark.

World Health Organisation (WHO) and Sigma Theta Tau International (2007) Global Standards for Initial Nursing and Midwifery Education. Geneva: WHO.

Mary Gobbi is a Senior Lecturer at the Faculty of Health Sciences, University of Southampton. She is an experienced educational evaluator and developer working in the areas of nursing skills and competence at EU level. Her scholarship focuses upon work based learning, simulation and their connections with scope of practice and regulation. 